\title{
VINDICATING CAPITAL: HEROES AND VILLAINS IN A LION'S TRAIL
}

Håvard Ovesen

University of Cape Town

Adam Haupt

University of Cape Town

\begin{abstract}
This paper analyses François Verster's A Lion's Trail (2002), a documentary about the late musician Solomon Linda and his hit song, Mbube. Linda died a pauper, despite the fact that his composition became one of the most commercially successful songs in the history of popular music. Considering the potentially substantial financial benefits due to Solomon Linda's daughters as heirs to his intellectual property rights, the story of Mbube can easily be read as having a happy, if somewhat bittersweet, ending. This ending is remarkably similar to the grand narrative of the new and democratic South Africa; in the end, justice was served, although not everybody was around to enjoy it. Such readings, however, obscure certain aspects of the new South African realities. The
\end{abstract}


power structures that enable the continuation of huge socioeconomic disparities are still in place. We contend that the film's characertisation of protagonists and antagonists in its narrative as well as the closure that is provided by the actions of Gallo allow viewers to overlook some key problems that persist in dominant assumptions about intellectual property, the ill-treatment of countless other black musicians during apartheid, as well as racialised class inequalities that persist nearly two decades after apartheid. The paper will commence with a brief description of Linda's career in order to set the scene for our analysis of Verster's documentary. This analysis will be informed by insights into intellectual property; we will then relate these insights to a discussion of South Africa's adoption of neo-liberal economic policies. In essence, we argue that, much like the country's implementation of neoliberal strategies like Black Economic Empowerment (BEE), the assumptions inherent in A Lion's Trail about intellectual property vindicate capital and, by implication, the racialised class divide in post-apartheid South Africa.

\section{Settting the scene}

In 1939 Solomon Linda and his band, Evening Birds, went for the second recording session of their careers. After a few false starts, they eventually nailed a successful recording of Mbube, a song written by Solomon Linda. Gallo records, which had commissioned the recording session, paid Linda ten shillings for his work, and thereby took over the intellectual property rights to the song, which became a fairly big hit in Southern Africa (Malan 3-37). Ten years later, American folk singer Pete Seeger came across the record. He faithfully transcribed the music, but, as he had no idea what the Zulu lyrics were, his version became the nonsensical Wimoweh. Seeger's publishers, TRO/Folkways, according to Seeger against his wishes, attributed the song writing credits to a 'Paul Campbell'. It was, at the time, common practice (and not entirely 
illegal either) to take traditional public domain songs and attribute them to fictitious composers, as a way to increase royalty income. Mbube, however, was not a 'traditional' tune; the 78rpm label clearly carried Solomon Linda's name, even if Gallo had traded the copyrights away to TRO/Folkways. While Pete Seeger's fortunes dwindled as a result of the red scare in 1950s America, the song lived on. In 1961, pop band The Tokens decided to give it a go. Successful songwriter George David Weiss, in collaboration with Hugo Peretti and Luigi Creatore, came in, rewrote and added lyrics, and rearranged the song substantially. The closing melody lines Solomon Linda had improvised in his recording gained a central place in the new version. The American songsmiths added the words "In the jungle, the mighty jungle, the lion sleeps tonight" to that melody line, making it the hook of the song. After an initial spat between TRO/Folkways and Abilene Music (the Weiss/Peretti/ Creatore publishing company), it was agreed that the song would be registered as written by Weiss/Peretti/Creatore, but based on a song by 'Paul Campbell'. No mention was made of Solomon Linda. This new version, The Lion Sleeps Tonight, became an evergreen, regularly topping charts in different incarnations (Malan 3-37). In 1990, however, the owners of Wimoweh and The Lion Sleeps Tonight again came to blows. The battle over ownership went to court, but was eventually settled in favour of Weiss and his publishers, when Weiss, upon learning of the song's African author, promised that $10 \%$ of the writer's royalties would be paid to Solomon Linda's estate (Malan 3-37). When Disney released The Lion King (1994) the song served as a focal point, both for the animated feature film as well as the stage version. The Disney production made the song surge in popularity, prompting George David Weiss, already a wealthy man, to praise God for his good fortunes (Malan 3-37). Solomon Linda's 
contribution to one of the biggest hit songs of all time was largely forgotten. He died in 1962. Despite having had a fairly successful career as an iscathamiya ${ }^{1}$ musician and having had a hit song that spawned an entire genre (mbube music), Linda left his daughters with little more than his Soweto house (Malan 3-37).

In 2000, journalist and music enthusiast Rian Malan broke the story of Solomon Linda in Rolling Stone magazine. Malan's article effectively drew up the fault lines: while Solomon Linda's daughters were living in poverty, George David Weiss, who, adding insult to injury, served as president of the Songwriter's Guild of America, was living it up in luxury in the United States. From Malan's investigation it was apparent that Linda's family had not received the promised ten percent. The apparent injustice done to Linda and the millions the song had earned for others involved became something of a South African cause célèbre (Malan 3-37). The Linda family's lawyer, Hanro Friedrich, working with Malan, started campaigning to try to improve the situation of the Linda daughters (Spoor \& Fisher, undated: online; Verster, 2002: documentary). In 2002, Gallo Records decided to cede all further income from Mbube to the Linda family and administer their copyrights for free. Gallo went on to hire lawyer firm Spoor \& Fisher, represented by South Africa's foremost copyright lawyer, Owen Dean, to try to ensure that Solomon Linda's daughters would benefit from the song. For his part, Friedrich managed to involve the Department of Arts and Culture, who agreed to partially fund the legal costs (Dlamini; Spoor \& Fisher, <http://www.spoor.com/home/index. php?ipkArticleID=245> 18 Oct. 2010). In 2004, TRO/Folkways gave in to the pressure of bad publicity and settled with Spoor \& Fisher. All of the composer's royalties for Wimoweh were ceded to the Linda family (Temkin; Modisane; Citizen Reporter/The Citizen; 
This Day/Sapa). In 2006, a settlement was reached with Disney, targeted along with other related South African companies by Spoor \& Fisher for their use of the song in their Lion King franchise. Part of the settlement was a confidentiality clause, so the details are not known. According to Spoor \& Fisher, however, it would be "appropriate compensation for past and future uses of the song" (Citizen Reporter/The Citizen). However, as late as 2009, the Linda family claimed that they had only received what they believed were a fraction of what they were entitled to from the Solomon Linda Trust Fund, set up as part of the settlement. They also maintained that the exact sum of the settlement had never been disclosed to them, and that they had difficulties communicating with the board of the trust. Owen Dean denied these allegations (McMahon; Oliphant, 2009a; 2009b).

\section{The Grand Narrative: A Lion's Trail}

François Verster's 2002 documentary, A Lion's Trail, attempts to detail the story of Mbube and the fate of Solomon Linda and his descendants. Along with Rian Malan's (2003) Rolling Stone article, it is the seminal work on this important tale of capitalist exploitation of underprivileged South Africans. Subjecting the documentary to a qualitative discourse analysis might thus shed important light on perceptions of copyright in a new and democratic South Africa eager on righting the wrongs of the past. As we shall see, A Lion's Trail is problematic. While it seeks to obtain justice for a man marginalised by his status as a black African musician in a racist and exploitative environment, in its eagerness to award Solomon Linda the status he rightly deserves, the film falls into the trap of utilising the same reductionist discourse. Not only is Linda reduced to a cardboard cut-out Zulu cliché by the documentary's main framing device, 
but, as a whole, the character gallery of the film feeds into a very Northern idea of the white man (gendering intended) as proactive and black people as deserving of his help. Furthermore, through its singling out of George David Weiss as the villain of the story, Verster takes focus away from structural causes of exploitation and poverty. The idea of intellectual property (and, remember, the idea of property underpins the entire capitalist system that got you, me, Solomon Linda's daughter, and George David Weiss, where we are today) is never challenged. It appears as if the inclusion of Linda's song and 'rightful' rights owners in the current copyright regime is a step toward equal integration and participation in South Africa's economy. In this section, as well as the next, which deals with the economic realities of contemporary South Africa, we shall argue that this is not necessarily the case.

\section{Winners and Losers in the New South Africa}

In the documentary, Joseph Shabalala of Ladysmith Black Mambazo, who hails from the same area as Linda, stands out as a socio-economic contrast to Linda. Visually, he is introduced by a shot of the gate to his compound. The way the camera dwells on the gate and his house as well as (later in the film) the interior of his Mercedes clearly portrays him as a successful musician, a product of the new South Africa. Similarly, the contemporary shots of the Manhattan Brothers, who rose to prominence in the 1940s and 1950s, rehearsing in a modern London recording studio drive home the point that these are musicians who have 'made it' in the new South Africa. The Manhattan Brothers sequence comes right after some grainy sepia-toned images from Johannesburg, further emphasising the new reality these musicians are working in. Unfortunately, Shabalala's character is the exception rather 
than the rule in A Lion's Trail. Clearly, if in Verster's tale, Rian Malan is the hero and George David Weiss is the villain, the Linda sisters are the victims of the story. While their poverty and illness is undoubtedly real and a cause for concern, their stoic suffering (one of the sisters, for example, is filmed humming the anthem of the new and democratic South Africa, Nkosi Sikelel' iAfrika while doing housework) and recourse to prayer leaves them with little room for agency. A lot of attention is devoted to the sisters' practice of ancestor worship and traditional medicine. According to Fildah, her father is poor even in death, "appearing as a hungry man, like a hobo." Fildah's contact with her dead father is one of the most moving scenes in the film. Yet at the same time, the continued focus on the sisters' prayers portrays them as passive victims, subject to the whims of the gods.

In Verster's documentary, Joseph Shabalala is the only black African subject given the authority to interpret and analyse Linda's song and contribution to the South African musical heritage in general. The Linda family are portrayed as patient and stoic victims of injustice, and whereas Joe Mogotsi and the rest of the Manhattan Brothers are filmed in a London recording studio, an indication that their economic fortune as musicians has changed, the story they tell in the documentary is nevertheless one of economic exploitation and victimisation of their younger selves by Gallo Records. Shabalala, on the other hand, is given ample space to contextualise the role of the lion in rural Zulu culture, as well as praising Solomon Linda and Mbube. Shabalala also points out the transgressive nature of the song. Given all the references to traditional Zulu culture which tend to crop up in the Mbube narrative, Shabalala's assertion that Linda's falsetto (at times bordering on ululation), broke with assigned gender roles at the time, seems quite significant. 
The emphasis on Linda as an innovator can of course be seen as harmonious with copyright's insistence on originality, and, as such, a vindication of the copyright system. This may be the case, but at the same time, Shabalala points out that the techniques Linda employed so successfully were already in use, but only by women. In light of this, one might say that part of Linda's genius was that he took elements that were already in the public domain, and reinvented them. Shabalala is portrayed as having agency; when referring to Ladysmith Black Mambazo's big international breakthrough, he corrects himself, saying "no, not Paul [Simon's], our Graceland tour". This is significant considering the allegations of Northern appropriation that have been levelled against Paul Simon in connection with the Graceland album (Meintjes 37-73; Pietilä 229-250). Indeed, it has been claimed that Simon unsuccessfully tried to buy the rights for the Sotho song on which Simon based The Boy in the Bubble (Pietilä 237). Although collaboration is a recurring motif on and selling point of Graceland, in the end, there is no doubt of who the author of the album is (Meintjes 40-48). Simon's dominant voice is obvious through his roles as lead vocalist, songwriter and producer. At times the album's relationship between the (white) American author and (black) South African musicians who appear mainly as wage labourers, suggest "a process of appropriation, exploitation, and domination" in a perverse replication of race and labour relations in South Africa at the time of the recording (Meintjes 47). Next to the alleged appropriation process, the fact that the musicians were well paid for their time and that they were given co-authorship credits (albeit in an inconsistent manner), as well as Simon's donations of money earned from the record to African and African-American charity causes take on an air of patronage rather than fair remuneration and genuine collaboration (Meintjes 47; 
Pietilä 237). Given this background, it is refreshing to hear Shabalala reappropriate the album and tour, as "our". Clearly, Shabalala is portrayed as a new generation of musician from Linda.

\section{Rian Malan: Action Man}

Despite Joe Mogotsi's damning testimonial of signing to Gallo Records in his younger years, and the considerable attention devoted to Linda's daughters, it is nevertheless left to Rian Malan to articulate moral indignation and contextualise the story of Mbube within a larger socioeconomic framework of economic exploitation. He comes across as the main protagonist in Verster's narrative; it is Malan's energy that drives events forward. It was he who first alerted Rolling Stone readers and the Linda family of the galling disparities between the fortunes made by American interpreters of the song and Solomon Linda's cash-strapped demise. According to Malan, the tiny trickle of royalties that had already found its way to South Africa dried up as a result of his pursuit of the story. At one stage, we see him at what appears as some sort of planning meeting with the South African Music Rights Organisation (SAMRO), where the indignation over how the Americans "[treat] these people and our country with absolute contempt" is clear. In light of later developments, the meeting with SAMRO appears highly ironic: After the 2006 settlement with Disney, there have been allegations that millions of Rands relating to publishing rights have been paid in to SAMRO, but have not been distributed to the Linda daughters. SAMRO, in turn, has denied ever receiving the money (Oliphant, 2009a).

Malan's understanding of the juridical side of the story is interesting. He is at pains to point out that the exploitation of Solomon Linda and his work was perfectly legal. To him, it is 
simply not fair, and a question of morality. He is thus on a quest to "[use] moral pressure to force a just and reasonable settlement of this matter." Malan tells us that this is his third year of working on this case together with an Afrikaner lawyer, and points out that while the case has "theoretically nothing to do with us," he has started to take the unashamed appropriation personally, and that they are on a "crusade for justice". Malan's considerable involvement and dedication to the story (indeed, without him the story might never have been told at all) is laudable, and might make his role as protagonist appear natural. In a certain sense, it is. However, this kind of narrative closely resembles Hollywood films taking on African misfortunes: as in Blood Diamond (2006) and Lord of War (2005), it is the white man who has done wrong in the past, and only the white man who can redeem the situation (and himself) through renewed involvement. Incidentally, this echoes the abolitionist debate in the sense that what was under debate was the form imperialism should take, not whether imperialism and colonial intervention was desirable at all (Comaroff \& Comaroff 8788). Africans become spectators to the white man's journey to his redemption (Rijsdijk 306). While "there is no shortage of cinematic images of Africa and Africans", woefully few of these are produced by Africans themselves (Sacks 15-16). Although not absolute, Hollywood narratives continue to dominate representation of Africa (Sacks 15-16). These narratives, driven by profit, have entertainment as their main focus, which in turn leads to charactercentred dramas, which demand clear unambiguous conclusions (Speidel 64-65). Disguised by an ostensible objective point of view, structural racism coupled with the profit motive leads to many Hollywood narratives inviting the audience to see the world from a white protagonist's view, as "white faces allow for empathy", 
thereby marginalising the importance of other characters' take on things (Calhoun 32-35; Francis 280-289). Both Lord of War and Blood Diamond take on such discourses. Both films deal with their white protagonists' continued exploitation of African suffering. While Africa serves as a dramatic backdrop, African characters are reduced to libidinous and/or senselessly violent characters, or they are hapless victims dependent upon the help and intervention of the white man. Blood Diamond ends with the white man mending his way, thereby supposedly putting an end to Africans exploiting each other for diamonds, whereas Lord of War comes to a more sinister conclusion: as long as the white man keeps supplying Africa with weapons, Africans will continue to kill each other for no apparent reason. In all three films Black Africans are thus reduced to passive victims and spectators, extras in their own drama.

\section{George David Weiss: The Bad Guy}

Malan's (and the film's) nemesis is George David Weiss. Weiss is the man who changed the melody around, added some lines, and renamed it The Lion Sleeps Tonight. He refused to be part of the movie. Verster nevertheless includes him, using stock footage from a cheesy old TV show, in which Weiss sings and talks about 'The Lion Sleeps Tonight'. By this time, the film has thoroughly covered what the word mbube means, as well as mapped out the song's journey from Johannesburg to the USA and then worldwide, and the numerous transformations it underwent along the way. Consequently, Weiss's assertion that "Mbube was a word used by Africans when they went into the jungle" to hunt lions, as well as taking credit for the entire song except the nonsensical word 'Wimoweh' (although he carefully omits to mention Pete Seeger's role), comes across as cynical, prejudiced and deceitful. 
That being said, the staging of Weiss as the main antagonist has some unfortunate side effects. Pete Seeger as well as Jay Siegel from the Tokens both get to condemn Weiss's attitude and greed without having to answer for their own complicity. It is as if they, too, are victims of Weiss. Many of the folk songs that Pete Seeger recorded with the Weavers were attributed to the pseudonymous composer 'Paul Campbell' by the Weavers and their publisher. The publisher assumed Mbube to be a traditional African song, and thus in the public domain. This practice of attributing public domain material to bogus entities was widespread at the time (Malan 20-23). In the documentary, when Seeger says that his big mistake was in not ensuring that his publisher enter into a written contract with Linda, he might be earnest, but he nevertheless sidesteps his complicity in theft from the public domain by not calling what happened by its right name. What was special about the Mbube case was that Linda's credit as composer was replaced with that of the fictitious Campbell (Malan 20-23). While Seeger might have been uncomfortable with this particular case, the fact that he is not interrogated about these dubious practices at all is a serious omission.

\section{Gallo Records: From Exploitation to Transformation?}

In 1939, Solomon Linda and his band, Evening Birds, recorded Mbube in the Johannesburg studio of Gallo Records. As we indicated before, Linda was paid ten shillings. Henceforth, Gallo Records would be the owners of the rights to Mbube. Within a decade, the Mbube 78 had sold 100000 units with the profits going straight to Gallo's owner, Eric Gallo (Malan 8-9). Today, Gallo Records is one of the decidedly biggest and most powerful record companies in South Africa (Pietilä 232-233). A Lion's Trail, however, does not 
dwell too long on Gallo's exploitation record. That is, as already mentioned, Joe Mogotsi from the Manhattan Brothers does deliver a damning testimonial of how he, with "no contract, no nothing," ceded all his rights to Gallo by signing a petty cash voucher. Mogotsi's perhaps most severe claim is that Gallo Records had told him that black people were not allowed to have royalties. Certainly, a royalty system for black people was slow to come and decidedly patchy when it started to arrive, although exploitation of white musicians happened too (Pietilä 234, 237-238). In any case, it is a bit puzzling that a record company which benefitted colossally from a very lax protection of black musician's rights, a regime arising from an undemocratic, racist and exploitative political economy, are not made to answer to Mogotsi's allegations. Instead, Gallo, which gave away their rights over Mbube in return for administering Pete Seeger's Wimoweh version in Southern Africa, are redeemed as repenting sinners in the ending credits of $A$ Lion's Trail. The ending credits simultaneously state that Gallo has decided to give all further income from the song to Linda's family, while "George David Weiss refused to cooperate in the making of this film" (Verster, 2002). If Weiss has been given the role as arch-villain, Gallo takes the role of the henchman-turned-good. Through a largely symbolic gesture, Gallo has redeemed itself from its dubious, if not downright immoral, practices. While undoubtedly useful as narrative strategies, the roles assigned to Seeger, Gallo, Jay Siegel of The Tokens and Weiss serve to obscure the nature of what happened to Solomon Linda; Weiss's rather unpleasant persona comes across as the main problem rather than systematic capitalist exploitation.

Gallo is now part of the media conglomerate Avusa Limited (formerly Johnnic Communications) (Pietilä 233). In 1996, the National Empowerment Consortium (NEC), in a record-breaking 
cash deal headed by Cyril Ramaphosa and discreetly encouraged by Nelson Mandela, bought half a billion Rands worth of controlling shares in Johnnic from Johannesburg Consolidated Investments (JCI), a division of Anglo-American (Gumede 410; Tomaselli 140142). From the side of mining giant Anglo-American, the sale was part of a restructuring process, as well as a way of accommodating the new government's focus on transformation (Tomaselli 141). The NEC was composed of over 50 black business groups, a number of which were actually the investment arms of various trade unions, many under the umbrella of ANC ally Congress of South African Trade Unions (COSATU). Later that year Ramaphosa withdrew from politics and became chairman of Johnnic (Barnett 654; Tomaselli 140-144).

It was hoped that the diversification of media ownership that began with Anglo-American's unbundling of Johnnic would lead to a more diverse and transformed public sphere. Unfortunately, such a transformation did not take place. In retrospect, it appears that class interests took precedence over racial solidarity. Media institutions in general remained committed to the same business model and principles, resulting in a continued exclusion of the masses and a limited role for a broad-based civil society (Tomaselli 144-152). In a classic example of how the process of hegemony works, the real novelty of the situation was that "surplus value that can only accrue from labor exploitation now belonged to union ownership" (Tomaselli 152). It is in this light that Gallo's promise to cede all further income from the work of Solomon Linda to his family must be seen: As a token gesture that will benefit and enrich a select few, but that leaves the structures of systematic exploitation unchanged. We see a reflection of the same pattern in newspaper references to Weavers publisher TRO/Folkways's 2004 
decision to acknowledge Solomon Linda as the rightful author/ co-composer of Mbube/Wimoweh and cede all future royalties to the Linda family. This decision did not come by itself, but was the result of a settlement between TRO/Folkways and Spoor \& Fisher, the South African law firm representing Gallo Records on behalf of the Department of Arts and Culture. While Disney is portrayed as the real villain, TRO/Folkways are presented as sinners who have seen the light, and questions around the practice of appropriating public domain songs under false names are never brought up. This is quite remarkable given that more than a few reports mention how the publishers thought the song was 'traditional' (a claim not compatible with Pete Seeger's account) (The Citizen, 2004; Khumalo, 2004; Latraniere, 2006; Modisane, 2004; Temkin, 2004; This Day/ Sapa, 2004). Out of six articles that mention the settlement, it is only music aficionado Fred Khumalo in This Day that goes beyond the notion that 'justice has been served', suggesting that this might be a starting point for ensuring that other local artists "might also get what is legally theirs" (Khumalo, 2004).

\section{The Exotic Zulu Author and the Acceptable Face of Capitalism}

The opening and ending of the film is unfortunate, both visually and textually. With Linda's recording of Mbube playing in the background we are presented with opening titles explaining to us that Mbube was written by the 'Zulu herdboy' Solomon Linda. While it is true that Solomon Linda indeed was a Zulu from rural Zululand, and that he, prior to moving to Johannesburg, herded cattle, Linda was, at the time that he recorded Mbube, an urban worker and musician. The term 'boy', in a Southern African context, is offensive. The history of the term in the region reflects white paternalistic attitudes: by denying the black man of adulthood, the 
term emasculated the subject and relegated the 'boy' to an inferior position in relation to that of the white man (Morrell, 1998: 616, 630). For Verster and A Lion's Trail to exoticize and essentialise Linda in this manner does not do him any justice. This tendency is further accentuated by the accompanying sepia-toned footage of Zulus wearing traditional garb hunting lions. The film ends in the same manner. Ironically, this framing of Linda and his song comes very close to George David Weiss's somewhat misguided explanation that 'Mbube' is something Africans say when they go into the jungle to hunt lion.

A Lion's Trail goes to great lengths to try to map out the story of a song, its authors, and its origins. Still, it bases itself upon the assumption that a text must have an author who somehow created something original. This is a questionable assumption. Mbube and its later incarnations, together with Joseph Shabalala's depiction of $M b u b e$ as both a continuation and reinvention of Zulu musical practices, ought to raise questions about the futility of searching for the ultimate author. ${ }^{2}$ Michel Foucault (1977) would explain this through looking at the author as a social construct. To Foucault, the author is a set of signs that indicate the values of a text and frames its context. Authorship is thus a discourse, the value of which is constantly in flux, reflecting changing values in society (Foucault, 1977: 121-128). Intellectual property rights have their roots in the Enlightenment project, and came into full force in parallel with the emergence of Habermas's $19^{\text {th }}$ century public sphere. The legal protection and regulation of texts favoured some forms of writing over others, thereby echoing and reinforcing the already existing power structures in the public sphere. Women, the lower classes, 'barbarians' and similar out-groups were not allowed access into this public sphere, as their contributions were not seen as having 
any value (Coombe, 1998: 252-256, 273). In the U.S., for example, slaves were not allowed to hold patents (Chander \& Sunder, 2007: 569). Whereas some forms of (written) expressions came to be seen as 'works of hire', pure commodities without artistic merit, the bourgeois book was seen as 'original' and worthy of protection. Intellectual property regulation thus invested the privileged with authority, legitimising some expressions and forms of meaning production over others, while it excluded the voice of the subaltern, thereby making the privileged position of some appear 'natural' and unchallenged. While some forms of political speech are typically exempt from intellectual property regulation, the power to declare some expressions as political (and others as 'apolitical') of course lies with the already established political elite (Coombe, 1998: 252$256,274-275,280)$. In such a discourse, a text only attains legitimate meaning and value once it is regulated by intellectual property regimes, a feature making poaching of the subaltern text the only way of validating it (Coombe, 1998: 253-255). Take for instance the meeting between the colonialist and the native during imperialism: While the natives were at times admired for their craft, theirs was nevertheless considered "functional objects; art was something European and civilized" (Halbert, 2005: 137-139). The Western discourse conceptualised this unprotected resource as pure raw material, out of which real value could only be created through privatizing and commoditising it, making it a truly 'modern' and 'civilized' expression (Halbert, 2005: 137-139). In later years, the practice of taking up elements from other cultures, infusing them with new meanings with the authoritative stamp that comes with author status has been critiqued as "cultural appropriation" (Coombe, 1998: 209-215). From a Foucaldian perspective, then, one might make the somewhat crude argument that the ostensible 
genius of the Western author lay in giving the text its 'brand value' (Foucault, 1977: 122-124, 126, 130). Seeing intellectual property as a discourse rather than law, it is not difficult to conceptualise the fate of Solomon Linda and Mbube, contra Wimoweh and The Lion Sleeps Tonight, as a product of unequal power structures.

Intellectual property rights must be seen in relation to the rise of the capitalist mode of production. It is the logical continuation of the enclosure of the commons and the rise of a capitalist bourgeoisie which, in turn, enabled the rise of an economy based on the mass manufacture of commodities (Wark, 2006: 171). If intellectual property rights were the product of the rise of the bourgeoisie, it follows, then, that the law can be construed as an arena in which class interests and power relations play out, with the elite "[managing] the transition from one mode of production to another" (Wark, 2006: 174). Such transitions are made possible by the consent of the masses. According to Gramsci, the elite is not only in its privileged position because of its control over the forces of coercion, but also because of its ability to provide "intellectual and moral direction" (cited in Pellicani, 1981: 31-32). This willingness to consent is what is known as hegemony. In light of Wark's above mentioned comments, it can be argued that the law (and hereunder intellectual property rights) functions as an arbiter of hegemony. To Gramsci, hegemony can be uncovered both by looking at cultural institutions as well as cultural practices (Holub, 1992: 78-80, 104). In our context, then, it follows that the hegemonic process can be detected in intellectual property regimes (institutions) as well as in the texts and peoples' relations to them (practice) that these regimes somehow regulate (or even ignore, which is also a way of relating to something). Foucault (1977: 121-124), for example, claims that the author is a social construct arising out of intellectual property law, 
which serves to perpetuate certain discourses. Who were considered authors, and who were not, was a reflection of that society's power structures. That, in 1930s South Africa, Solomon Linda was not considered an author worthy of protection thus might not come as a big surprise. Unfortunately, in its eagerness to redeem this situation and award to Linda the status that he deserves, $A$ Lion's Trail takes on a very patronising tone with roots in the European imperialist discourse: in the new South Africa, even 'Zulu herdboys' can be authors. A brief overview of South Africa's economic policy after apartheid would be helpful here.

\section{Making sense of it: economic policy in the 'new' South Africa.}

In 2007, thirteen years after the African National Congress (ANC) first came to power, the South African economy had grown by thirty-three per cent. At the same time, forty-one per cent of the population were still living on or below one dollar per day (Gumede, 2007: 115-116). In these thirteen years the rich got richer while the poor got progressively poorer. Unemployment has gone up to a level at which "over half the working population is jobless" (Johnson, 2009: 61). In fact, since the advent of democracy, the disparities between rich and poor have reached unprecedented levels (Gumede, 2007: 115-116). While realities in democratic South Africa seemingly have failed to live up to the Freedom Charter ${ }^{3}$, the government's answer tends to be black economic empowerment (BEE) deals (Johnson, 2009: 72). The thinking behind BEE is that a black economic elite, through a set of policies aimed at rewarding affirmative action in business deals, will emerge and gradually "become the vanguard of black integration into the economic mainstream" (Iheduru, 2004: 2). Once this vanguard is in place, the power relations in society will change, and wealth from the front 
line black bourgeoisie will somehow trickle down to the rest of the economy, thereby further deracialising it (Gumede, 2007:286, 289). Prominent black businesswoman Wendy Luhabe has thus defended the BEE class project as an experiment in "economic democracy" (2007: 21-22) intended to help the South African economy to grow and become internationally competitive (Luhabe, 2007: 19). This will be achieved through three main goals: the development of a black middle class, increased black control of and ownership in the economy, and a wider dissemination of skills among Africans (Sanchez, 2008: 209). For all its noble intentions, BEE appears not to have had a substantial impact on South Africa's rather harsh socio-economical realities: In 2004, it was estimated that the white population (less than ten percent of the total population) still controlled over 85 percent of the economy (Iheduru, 2004: 21). It is indisputable that a black upper middle class has emerged. However, in 2008, the black middle class was estimated to consist of no more than 3 million people; roughly 6 percent of the population (Du Toit \& Van Tonder, 2009: 16).

The key to understanding contemporary South Africa is to be found in the 1990-1994 transition period (Bond, 2009: 77). The ANC was ill prepared for its own unbanning and the subsequent negotiations. To the extent that economic planning had been done, it was based on models no longer applicable in a postCold War environment. The lack of concrete policies and internal disagreements over which economic route to take, left the ANC vulnerable to influence from local and international business, the media, the disciplining force of capital flows, and the Bretton Woods institutions (Gumede, 2007: 79, 84-85, 100). Struggling to make sense of its new realpolitikal surroundings, the ANC was unable to resist the pressure from its new-found friends in business 
and international institutions (Bond, 2009: 78-79). Domestically, the white oligarchy that dominated the mining and energy sector before and during the transition to democracy was keen to preserve its hegemony. Worried about the Freedom Charter's calls for nationalisation, the sector offered up BEE as an alternative during the Convention for a Democratic South Africa (CODESA) II negotiations. The emerging black political elite acquiesced to this (Mbeki, 2007: 221-222). As such, it is clear that the upper echelons of the struggle movement were bought out and co-opted with what appeared "like a transfer to them of massive assets at no costs" (Mbeki, 2009: 67). Still, poor service delivery, rising unemployment and an abysmal education system cannot be blamed on the ruling alliance alone. Macroeconomic policies encouraged (or sometimes imposed) by the Bretton Woods institutions as well as local and international capital in the years leading up to 1994, are a core part of the problem. What is clear, however, is that the ANC quickly became supporters of these policies, and have since 1994 actually geared up the implementation of neoliberal policies friendly to global capital. An example of this is the lifting of capital controls (Bond, 2009: 80-81). To explain this newfound enthusiasm for economic orthodoxy, it is necessary to look closer at the convergence of South Africa's two elites.

South Africa's ruling class can roughly be described as consisting of two main groups: the politically dominant black upper middle class and the (largely white) "economic oligarchy" (Mbeki, 2007: 216) which dominates the mining, energy, and finance sectors. Together, these groups have the power to define transformation (Mbeki, 2007: 216-217). This is highly relevant, as it was these two groups that together fleshed out South Africa's socio-economic future during negotiations in the early 1990s. It is, then, perhaps no surprise that the consensus that emerged 
was that globalisation combined with BEE in a liberal democracy would result in transformation (Mbeki, 2007: 217). The upswing of this approach has been stability and economic growth. Unfortunately, the same policies have resulted in the entrenchment of a vast (and growing) underclass, in large thanks to the erosion of manufacturing industries unable to compete with cheap imports from Asia (Mbeki, 2007: 221223). The main beneficiaries of this development have been the mining and energy oligarchs who have been able to preserve their business methods and thus their privileges and positions, as well as a "new class of unproductive, rich black politicians and ex-politicians," who together with the energy and mining oligarchs have a vested interest in the preservation of the status quo (Mbeki, 2007: 222). In this light, the notion that transformation has been hijacked by elites to serve their own interest quickly springs to mind.

For the ANC in the early 1990s, a major motivation for pushing for the creation of a black economic elite was the idea that racial solidarity would motivate black business to uplift the poor (Iheduru, 2004: 6). Unfortunately, this effect has yet to materialise. So far, there is little evidence that the creation of a BEE elite has led to any substantial black job creation or trickle-down effects (Iheduru, 2004: 20-21). Black business leaders have engaged in capitalist practices as exploitative as any, and there is no reason to assume that the new black upper class feels any more corporate responsibility than their white counterparts (Gumede, 2007: 290291). Allegations have been made that BEE might actually have had a detrimental effect on corporate social investment; some businesses see little need for demonstrating further corporate responsibility, as their BEE credentials ostensibly already bear witness to their socially responsible character (Friedman, Hudson \& Mackay, 2008: 211). While philanthropy does not seem particularly popular with 
BEE capitalists, it is nevertheless interesting in terms of political economy and elite convergence to note the apparent enthusiasm with which they make political donations (Gumede, 2007: 291).

In some cases it is evident that BEE rhetoric and practices, far from redressing racially-based capitalist exploitation, can actually entrench the same exploitative practices, sans racist rhetoric or intentions (Bezuidenhout, 2008: 200). The South African mining industry has a long and well-documented history of exploitation and externalisation of social costs (Bezuidenhout, 2008: 181182). Mining's iron grip on the working class was not successfully challenged until the 1980s, when organised labour finally made inroads into improving working conditions and contractual rights. These new-won rights were further entrenched by South Africa's new government in the 1990s (Bezuidenhout, 2008: 181182). Improved rights for workers, however, do not necessarily translate into a bigger profit for mining companies. Since 1994, the successes of organised labour have steadily been undermined by three business counterstrategies: casualisation, externalisation and informalisation (Bezuidenhout, 2008: 182-183, 186-187). Instead of employing workers with standard contracts, many businesses have taken to hiring people part-time, to do piece-work or casual work instead. Likewise, the subcontracting and outsourcing of work reduces a company's obligations towards its workers. Together, these trends constitute an informalisation of relations between employer and employee, a tendency that is further exacerbated by other complex and obscure, if not downright illegal, business relationships (Bezuidenhout, 2008: 186-187). These practices lead to a deterioration of workers' rights, as subcontracted workers often do not have access to or are discouraged from union membership. Generally, their salaries are substantially lower than those of 
workers who enjoy standard contracts; they enjoy fewer benefits, and perform more dangerous tasks. However, it is not just the individual workers that are marginalised. Since fewer people enter into formal employer-employee relationships with mining houses, the bargaining position of labour unions is gradually weakened, something which, in turn, weakens the position of the working class as a whole (Bezuidenhout, 2008: 194-196). In themselves, these practices are not particular to South Africa but part of modern global business practices (Bezuidenhout, 2008: 186). What makes them worth pointing out in our context though, is that business restructuring like this, is done as part of a project in which black economic empowerment ostensibly is the goal (Bezuidenhout, 2008: 197, 199). This is hegemony at work, and closely resembles the story of Mbube. Outsourced services, for example, might subsequently be undertaken by a BEE company. Thus, what we see is a situation in which "the empowerment of some is often built on the disempowerment of others" (Bezuidenhout, 2008: 186). In so many words, the convergence of globalised business practices and the desire to create a black economic elite has resulted in a socioeconomic environment in which "policies intended to bring about empowerment are paradoxically contributing to and legitimising the creation of new layers of exclusion" (Bezuidenhout, 2008: 179).

\section{Empowerment of the Few Means Business as Usual (or Worse) for the Masses}

Generally, a situation is emerging in which capitalism is being vindicated by black entrepreneurship, despite the continued low levels at which it takes place (Iheduru, 2004: 19). The South African Constitution's recognition of a new group of people, previously 
disadvantaged persons, a category under which the vast majority of South Africans fall, serves to perpetuate the idea that "all black South Africans could or would benefit from BEE" (Mbeki, 2009: 6869). Thus, the continued enrichment of the wealthy is legitimised with the hint that BEE will, in time, benefit the masses (Mbeki, 2009: 69). We have already seen how the unions have been weakened by corporate restructuring. However, the left has also willingly let itself be co-opted by capital: one would be forgiven for thinking that leftist hardliner stances might very well become increasingly rare as unions themselves have established investment companies and other large-scale businesses dependent on a continuation of the status quo (Iheduru, 2004: 18-19). Ironically, a notable feature of the black political elite's complicity in the continuation of exploitative capitalist practices is its rhetorical window-dressing. Despite the obvious and systematic implementation of pro-capital policies, it appears that the political establishment's redistributionist rhetoric "reaches its height when defending government policy against criticism from the left" (Bond, 2009: 83). The rhetoric surrounding BEE deals celebrate them as a democratising and equalising feature, when the only newcomers to the table consists of a narrow black elite with close ties to the government and the ANC (Johnson, 2009: 65-68). Again, one is reminded of Gallo Records' token award of composer's rights to the Linda family and the Department of Arts and Culture's involvement in the negotiation and litigation processes with Disney and TRO/Folkways. As with BEE, an economic policy that mainly serves the elite is being championed as a vehicle for transformation. As should be clear by now, for the great majority of South Africans, the emergence of a small black business elite has not lead to substantial improvements on the ground. South Africa's economy continues to grow, but at the expense of those who can 
afford it the least. What has changed with the emergence of BEE capitalism, however, is the apparent renewal of legitimacy enjoyed by rampant exploitative capitalism. The lifestyles of conspicuous consumption in the face of abject poverty are an inheritance from the old white elite, but while the old business elite was shunned internationally because their wealth was derived from capitalist exploitation based on racism, the emerging BEE elite has made this kind of exploitation legitimate (Gumede, 2007: 296; Johnson, 2009: 63). The enrichment of a lucky few who until recently were formally barred from entering into big business thus serves as a legitimating device for a continued capitalistic oppression of the many, a structural feature that, apart from a few black faces on the top, largely continues to function along racial lines.

\section{Conclusion}

Just as government-endorsed BEE deals and policies have served as the legitimation of an already established elite, so we find that the narrative of Mbube appears to vindicate intellectual property regimes. As we have seen, the roots of today's intellectual property rights regimes are to be found in the emergence of the bourgeoisie in nineteenth century Europe. These rights are not 'natural' or given, but reflect the power structures in place in Europe at the time, and continue to reinforce the same patterns today. In many ways, the law, hereunder intellectual property rights, functions as a place where hegemony can be negotiated between competing elites and the masses. Hardt and Negri's concept of Empire (2001) is useful in understanding South Africa's post-apartheid turn toward liberalisation and internalisation of the Washington Consensus (Gumede, 2007: 106, 109). While Hardt and Negri stress that there are differences between Empire and the imperialism of old, 
it is nevertheless possible to identify some power mechanisms as inheritances from South Africa's colonial and racist past. In terms of intellectual property, we find that between the North and South as a whole the trade is lopsided in favour of the North just as it always was. However, with the emergence of Empire these imbalances are increasingly replicated within the country. While South Africa's political make-up might have changed, the power structures are still in place, partially held up through discursive strategies. The story of how Solomon Linda got back his authoring rights over Mbube is framed as if social justice has been served. The change in the global political economy following the end of World War II and later the fall of the Soviet Union partially removed the old geographically-based centre-periphery dichotomy. In its place came a globalised capitalism, but one that continues to rely on the same exploitative practices and that is in continued need of legitimation. Hence, South Africa's elites have a vested interest in maintaining the status quo while giving the impression that the struggle for social justice continues. Such a framework explains the Department of Arts and Culture's support for the court case against Disney: Intellectual property, a property system initially designed to benefit European elites is reframed as a weapon with which to fight poverty.

François Verster's documentary, while undoubtedly wellmeaning, nevertheless plays into a discourse in which black people mainly appear as victims depending on white people's involvement. The film appears decidedly in favour of the current intellectual property regime. In its quest for 'justice' for Solomon Linda and his daughters the documentary never questions the notion that locking down a text with intellectual properties seventy years after it was written and forty years after the death of the author is just. The 
value of a public domain is simply never considered at all. Instead we are presented with a false binary: whether to redistribute some property from white to black ownership or not. Just like the case was after South Africa's transition to democracy, it is a question of (cosmetic) redistribution, not a change to the system. In the same way as capitalist and exploitative practices have been allowed to continue in South Africa, seemingly legitimised by a handful of token black capitalists, so, too, is the idea of an extensive intellectual property rights regime never questioned. Instead, we are presented with an argument to redistribute a particular piece of property from white ownership to black ownership. That the underlying structures ought to remain the same appears given. Thus Gallo can decide to cede their rights to Solomon Linda, but nevertheless keep their rights to other songs acquired in the same manner, without ever being questioned about it. The fact that Gallo is under the umbrella of Avusa, a holding company owned by Black Economic Empowerment (BEE) capital, is, as we have seen, arguably emblematic of the economic realities of the new South Africa.

While the ANC initially had plans for radical economic change upon the seizure of political power, once they found themselves on their way to office, they were ill prepared for the realpolitikal economic dilemmas waiting for them. They were thus easily co-opted by actors, whether domestic or international, that had a vested interest in the continuation and extension of already existing capitalist structures. The ANC arguably failed to provide substantial change for its constituency, who remain trapped in a cycle of poverty. What change the ruling party did manage to instigate was mainly cosmetic while at the same time it entrenched the ANC's continued interest in a liberalised South 
Africa. Essentially, through BEE, the ANC created a small black economic elite, that was largely recruited from within the ranks of the black political elite. This new economic elite, in turn, was dependent on the continued success of their white counterparts, as they had interests in the same operations. Hence, South Africa's elites' interests are converging, with economic policies firmly attached to the Washington Consensus. These policies, that do little to relieve the situation of the poor, are legitimised through their apparent focus on 'transformation', through encouraging preferential treatment of black business people and the somewhat vague idea that this will result in a trickle-down effect that in the long run, will benefit the poor.

Here we come back to the restoration of Solomon Linda as the author of Mbube: Both are examples of hegemonic discourses. Policies that lead to gains for the elite but have largely detrimental results for the masses are venerated as vehicles of transformation, through which justice will be served. Both are discourses that make certain power relations and structures of exploitation appear 'natural' and given, and any criticisms of these can thus easily be dismissed as reactionary. In essence, the film inadvertently vindicates capital.

\section{Notes}

1. Isicathamiya is the music style that succeeded mbube music (Coplan 60). David Coplan defines it as a "style of Zulu indigenous a capella male choral music and step dancing influenced by Christian hymnody and tracing its roots back to the early twentieth century in Natal" (Coplan 440).

2. It is interesting to note that nobody brought up the role of Evening Birds. If they recorded it together, and parts of the song were improvised, how can we be sure that it was all created by Solomon Linda? In this regard, Veit Erlmann writes, "While neither the words of 'Mbube' nor its anchorage in a wedding song were particularly original, in the view 
of Evening Birds member Gilbert Madondo, it was Linda's performance style innovations that revolutionized migrant workers' choral performance styles" (167). Erlmann therefore seems to suggest that it was Linda's performance style more than his composition that made the song noteworthy. From this perspective, a number factors, along with Linda's artistic contribution, lead to the success of the song.

3. The Congress of the People adopted the Freedom Charter in June 1955 at Kliptown (Rumney 421). Reg Rumney writes that the ANC policy document "inspired generations of ANC cadres" (403). The document made nationalisation of the mines and the banking industry a priority.

\section{References}

Barnett, C. “The Limits of Media Democratization in South Africa: Politics, Privatisation and Regulation". Media, Culture \& Society 21.5 (1999): 649-671.

Bezuidenhout, A. "New Patterns of Exclusion in the South African Mining Industry". A. Habib and K. Bentley eds. Racial Redress \& Citizenship in South Africa. Cape Town: HSRC Press, 2008.

Bhabha, H.K. The Location of Culture. 1994. New York: Routledge, 2010.

Bond, P. "In Power in Pretoria? Reply to R.W. Johnson". New Left Review 58 (2009): 77-88.

Boyle, J. The Public Domain: Enclosing the Commons of the Mind. New Haven and London: Yale University Press, 2008.

Calhoun, D. "White Guides, Black Pain". Sight and Sound 17.2 (2007): 3235.

Chander A \& Sunder M. "Is Nozick kicking Rawls's Ass? Intellectual Property and Social Justice”. UC Davis Law Review 40 (2007): 563-579.

Citizen reporter. "Lion sleeps with big bucks". The Citizen. 28 Sep. 2004.

Comaroff, J and Comaroff, J. Of Revelation and Revolution: Christianity, Colonialism, and Consciousness in South Africa Volume I. Chicago and London: University of Chicago Press, 1991. 
Coombe R. The Cultural Life of Intellectual Properties: Authorship, Appropriation, and the Law. Durham and London: Duke University Press, 1998.

Coplan, David B. In Township Tonight! South Africa's Black City Music and Theatre. 1985. Chicago and London: University of Chicago Press, 2007.

Davies G. Copyright and the Public Interest. London: Sweet \& Maxwell, 2002.

Du Toit, C and Van Tonder, J. "South Africa's Economic Performance Since 1994: Can We Do Better?”. R. Parsons ed. Zumanomics: Which Way to Shared Prosperity In South Africa? Challenges for a New Government. Auckland Park: Jacana, 2009.

Erlmann, Veit. African Stars: Studies in Black South African Performance. Chicago and London: University of Chicago Press, 1991.

Foucault, M. Language, Counter-Memory, Practice: Selected Essays. D. Bouchard ed. D. F. Bouchard and S. Simon trans. Oxford: Basil Blackwell, 1997.

Francis, T. "Ethnicity, Race, and Cinema -African-American Film". Introduction to Film Studies. J. Nelmes ed. London \& New York: Routledge, 2007.

Friedman, S, Hudson, J and Mackay, S. “The Colour of Giving: Racial Identity and Corporate Social Investment". A. Habib and B. Maharaj eds. Givinge Solidarity: Resource Flows for Poverty Alleviation and Development in South Africa. Cape Town: HSRC Press, 2008.

Frith, S and Marshall, L. "Traditional Music Ownership in a Commodified World". S Frith and L Marshall eds. Music and Copyright. Edinburgh: Edinburgh University Press, 2004.

Gumede, W. M. Thabo Mbeki and the Battle for the Soul of the ANC. Revised edition. Cape Town: Zebra Press, 2007.

Halbert, D. J. Resisting Intellectual Property. London and New York: Routledge, 2005.

Hardt, M. and A. Negri. Empire. Cambridge and London: Harvard University Press, 2001. 
Haupt, A. Stealing Empire: P2P, Intellectual Property and Hip-Hop Subversion. Cape Town: HSRC Press, 2008.

Holub, R. Antonio Gramsci: Beyond Marxism and Postmodernism. New York and London: Routledge, 1992.

Iheduru, O. C. "Black Economic Power and Nation-Building in PostApartheid South Africa". Journal of Modern African Studies 42.1 (2004): $1-30$.

Jonker, J. My Life in the Bush of Ghosts (Fear of Ghosts), 2008, unpublished.

Johnson, R.W. "False Start in South Africa”. New Left Review 58 (2009): 6174.

Khumalo, F. "Wimoweh royalties start to roll”. This Day 2 Jul. 2004.

Latraniere, S. “The Lion Sleeps Tonight-anything but a lullaby”. Daily Dispatch 24 Mar. 2006.

Lessig, L. Free Culture: The Nature and Future of Creativity. London: Penguin, 2004.

Luhabe, W. "The Moral Bases of a Stakeholder Society". G. Marcus, X. Mangcu, K. Shubane and A. Hadland eds. Visions of Black Economic Empowerment. Auckland Park: Jacana, 2007.

Malan, Rian. "Money, Greed and Mystery”. Rolling Stone. (2000): 54-66, 8485.

Mbeki, M. "Concepts of Transformation and the Social Structure of South Africa”. G. Marcus, X. Mangcu, K. Shubane and A. Hadland eds. Visions of Black Economic Empowerment. Auckland Park: Jacana, 2007.

Mbeki, M. Architects of Poverty: Why African Capitalism Needs Changing. Johannesburg: Picador Africa, 2009.

McMahon, M. "Zulu Lion That Made Disney Roar”. Sunday Independent 14 Sep. 2008.

Meintjes, L. "Paul Simon's Graceland, South Africa, and the Mediation of Musical Meaning”. Ethnomusicology 34.1(1990): 37-73.

Modisane, K. "Lion sleeps tonight as row nears end”. The Star 28 Sep. 2004. 
Morrell, R. "Of Boys and Men: Masculinity and Gender in Southern African Studies”. Journal of Southern African Studies 24.4(1998): 605-630.

Pellicani, L. Gramsci: An Alternative Communism? Trans. M. ManfriniWatts. Stanford: Hoover Institution Press, 1981.

Pietilä, T. "Whose Works and What Kinds of Rewards?" Information, Communication \& Society 12.2 (2009): 229-250.

Oliphant, L. "Lion King's heirs in painful fight". City Press 21 Jun. 2009a.

Oliphant, L “Our Trust Has Been Misplaced”. City Press 21 Jun. 2009b.

Rijsdijk, I. M. “The White Man's Curse: Stander and the Last Samurai”. Botha, M. ed. Marginal Lives \& Painful Pasts: South African Cinema After Apartheid. Parklands: Genugtig!, 2007.

Rotberg, R. I. The Founder: Cecil Rhodes and the Pursuit of Power. Johannesburg: Jonathan Ball Publishers, 2002.

Rumney, Reg. "Who Owns South Africa: An Analysis of State and Private Ownership Patterns". State of the Nation: South Africa 2004-2005. John Daniel, Roger Southall and Jessica Lutchman eds. Cape Town: HSRC Press, 2005.

Sacks, L. Cinema in Democratic South Africa: The Race for Representation. Bloomington and Indianapolis: Indiana University Press, 2010.

Sanchez, D. "Transformation in Small, Medium and Micro Enterprises”. A. Habib and K. Bentley eds. Racial Redress \& Citizenship in South Africa. Cape Town: HSRC Press, 2008.

Seeger, A. "Traditional Music Ownership in a Commodified World". S. Frith and L. Marshall eds. Music and Copyright. Edinburgh: Edinburgh University Press, 2004.

Seekings, J. and N. Nattrass. Class, Race, and Inequality in South Africa. Pietermaritzburg: University of KwaZulu-Natal Press, 2006.

Speidel, S. "Film Form and Narrative". Introduction to Film Studies. J. Nelmes ed. London and New York: Routledge, 2006.

Temkin, S. “Settlement of 'Lion' song dispute in sight”. Business Day 28 Sep. 2004. 
This Day/Sapa. "Family of Wimoweh songwriter should sleep well tonightthe lion must wait". 28 Sep. 2004.

Tolsi, N. "Ghost in the Machine”. Mail \& Guardian 12-19 Oct. 2006.

Tomaselli, K.G. "Media Ownership and Democratisation". G. Hyden, M. Leslie, and F. Ogundimo eds. Media and Democracy in Africa. New Brunswick: Transaction Publishers, 2002.

Wark, M. "Information Wants to Be Free (But Is Everywhere in Chains)". Cultural Studies 40.2-3(2006): 165-183.

Woods, N. "International Political Economy in an Age of Globalization". J. Baylis and S. Smith eds. The Globalization of World Politics: An Introduction to International Relations. Third edition. Oxford and New York: Oxford University Press, 2005.

\section{Films}

Allers, R and Minkoff, R. The Lion King. Walt Disney Feature Animation, 1994.

Niccol, A. Lord of War. Lions Gate Entertainment, 2005.

Verster, F. A Lion's Trail. Undercurrent Film \& TV / Lion's Trail Productions, 2002.

Zwick, E. Blood Diamond. Warner Bros. Pictures, 2006.

\section{Internet Resources}

Borland, R. (undated) Song of Solomon. <http://ralphborland.net/sos/ index.html $>12$ Oct. 2010.

Malan, R. In the Jungle. $2^{\text {nd }}$ ed. Cold Type Modern Classics. $2003<$ http:// www.coldtype.net>01 Mar. 2010.

ShuttleworthFoundation.ReportontheSouthAfricanOpenCopyrightReview.2008. $<$ http://www.shuttleworthfoundation.org/sites/shuttleworthfoundation.org/ files/SA_Copyright_Review_Report_09_v3.5.pdf> 28 Apr. 2010.

Spoor and Fisher (undated) The Lion Song Fact Sheet. <http://www.spoor. com/home/index.php?ipkArticleID=245> 18 Oct. 2010. 
Xingawa, L. Address by the Minister of Arts and Culture, Ms Lulu Xingwana, MP at the funeral of the late Winston 'Mankunku' Monwabisi Ngozi, Cape Town. 2009. <http://www.dac.gov.za/speeches/ minister/2009/24OctSpeech.html> 23 Apr. 2010.

[Received in 22/07/2011.Approved in 07/12/2011] 
